\title{
The Unconstitutionality of "Antihomeless" Laws: Ordinances Prohibiting Sleeping in Outdoor Public Areas as a Violation of the Right to Travel
}

\author{
Paul Ades†
}

I just spent sixty days in the jailhouse

For the crime of having no dough.

Now here I am, back on the streets again,

For the crime of having nowhere to go.

The Band ${ }^{1}$

On June 4, 1987, in response to repeated coinplaints from neighborhood businesses and residents, forty Los Angeles police officers swept througli the city's skid row areas to remove homeless individuals from the streets. ${ }^{2}$ Hundreds of liomeless people were forced to abandon tlieir makeshift slielters because tliey were violating a previously unenforced ordinance prohibiting sleeping on a street, sidewalk, or other public way. $^{3}$ The police tossed personal possessions into the street and threatened to arrest tliose liomeless people wlio refused to move or accept housmg voucliers. ${ }^{4}$

Many cities liave ordinances that similarly prohibit sleeping im certain public areas. ${ }^{5}$ Indeed, many municipalities, including Dallas,

$\dagger$ B.A. 1985, Williams College; third-year student, Boalt Hall School of Law, University of California, Berkeley. The author wishes to thank Mark Abbott, Rosemary Filou, and Helen Norton for their valuable assistance.

1. The Shape I'm In, J. Robbie Robertson, (๑ Canaan Music Inc. (1970). All rights reserved.

2. N.Y. Times, June 6,1987 , at 8 , col. 1 . A local store manager described the homeless as "bums-winos and bums who won't work." A sign in front of his store conveyed a similar message: "Feel sorry for the homeless?? Adopt one! Take one home with you today. Let them use your yard for a bathroom." Id. at 8, col. 2-3.

3. Los ANGeles, Cal., Municipal Code $\S 41.18$ (d) (1980). See also L.A. Daily J., June 4, 1987, at 23, col. 4 (describing the planned sweep and the unsuccessful application for a temporary restraining order against it).

4. N.Y. Times, supra note 2, at 8, col. 1.

5. See, e.g., Phoenix, Ariz., CITY CODE § 23-48.01 (1981) ("It shall be unlawful for any person to use a public street, highway, alley, lane, parkway, [or] sidewalk ... for lying [or] sleeping ... except in the case of a physical emergency or the administration of medical assistance.)"; See generally Seeley v. State, 134 Ariz. 263, 655 P.2d 803 (Ct. App. 1982) (finding ordinance constitutional); infra text accompanying notes 202-06. 
Texas ${ }^{6}$ and St. Petersburg, Florida,${ }^{7}$ have recently adopted or begun vigorously enforcing broadly written ordinances that prohibit outdoor sleeping in all public areas. ${ }^{8}$ For instance, in Santa Barbara, California, police officers enforcing a city ordinance prohibiting public sleeping ${ }^{9}$ wrote over 1,000 citations during 1985 and the first half of $1986 .{ }^{10}$

Other cities that hope to drive away their hoineless populations have conteinplated or are conteinplating adoption of ordinances that would prohibit sleeping in all public areas. For exainple, in 1986, Long Beach, California considered adopting an ordinance that would have prohibited sleeping outside of dwellings between 10:00 p.in. and 6:00 a.m. ${ }^{11}$ Such ordinances apply predominantly to the conduct of the homeless. Indeed, the proposed ordinances are admittedly ${ }^{12}$ intended to drive the homeless out of the sponsoring muincipalities. ${ }^{13}$

Federal constitutional issues raised by antisleeping legislation have received conflicting and imconsistent judicial treatment. Two courts, rejecting claims that such ordinances are vague and overbroad, have held

6. Dallas, TeX., Rev. Code of Civ. and Crim. Ordinances §31-13 (1986). See generally Pollard v. State, 687 S.W.2d 373 (Tex. Ct. App. 1985) (suggesting that a "culpable mental state" is a necessary element of a violation of the Dallas ordinance).

7. The St. Petersburg city ordinance provides that: "No person shall sleep upon or in any street, park, wharf or other public place." ST. PeTersburg, Fla., Ordinance 25.57 (1973).

8. Many jurisdictions have more limited ordinances which prohibit sleeping in a particular place. See, e.g., 36 C.F.R. $§ 7.96(i)$ (1988) (prohibiting "sleeping activities, or making preparations to sleep . . . or storing personal belongings" in parks or the National Capital District, except in designated campgrounds). Section 7.96(i) succeeds 36 C.F.R. $\$ 50.27$ (a), repealed in 1986. FED. REG. 37,011, 37,019 (1986). Section 50.27(a) withstood a constitutional challenge in Clark v. Community for Creative Non-Violence, 468 U.S. 288 (1984) (federal agency permitted to prohibit sleeping in national parklands). This Comment does not address the constitutionality of these morc limited ordinances, but rather examines only those ordinances that proscribe sleeping in all outdoor public areas.

9. Section 15.16.085 of the Santa Barbara, Cal., Municipal Code provided: "It shall be unlawful for any person to sleep in: (1) any public park during the period of time from 10:00 p.m. to 6:00 a.m.; (2) any public street; (3) any public parking lot or public area." See generally People v. Davenport, 176 Cal. App. 3d Supp. 10, 222 Cal. Rptr. 736 (1985) (upholding ordinance against several constitutional challenges), cert. denied, 475 U.S. 1141 (1986). A first offense carried a fine of $\$ 100$, a second \$200, and a third \$250. L.A. Times, April 29, 1986, Pt. I, at 3, col. 4.

In August 1986 the Santa Barbara city council revised this ordinance to prohibit sleeping only in public parks. N.Y. Times, Aug. 21, 1986, at A16, col. 4. However, a related ordinance continues to prohibit "camping" in all public areas. See Santa Barbara, Cal., Municipal Code $\$ 15.16 .070$ (1986). Conceivably, the word "camping" can be construed broadly enough to prohibit the homeless from setting out their belongings and sleeping outdoors.

10. Many of the citations resulted in arrests. N.Y. Times, supra note 9.

11. L.A. Times, July 27, 1986, pt. IX, at 1, col. 1. The ordinance was never adopted, in part because of doubts as to its constitutionality. Telephone interview with John VanderLans, City Prosecutor for Long Beach, California (Feb. 15, 1989).

12. For example, the senior assistant city attorney for Glendale, California stated that a proposed anti-sleeping ordinance was "aimed at pushing transients out of town." L.A. Times, May 25,1985 , Pt. III, at 17, col. 1 (valley ed.).

13. See infra notes 181-82 and accompanying text. 
that laws that prohibit sleeping in outdoor public areas are within a government's police power when they are directed at controlling "unsafe and unsanitary living situations which pose a tlireat to ... peace, health and safety." 14 Anotlier court uplield an antisleeping ordinance by assuming it required a "culpable mental state" on the part of the violator. ${ }^{15}$ An Arizona court upheld a Phoenix law banning outdoor sleeping against claims that it violated the right to travel and the equal protection clause. ${ }^{16}$ In these cases, the courts declined to address other constitutional claims raised by the defendants.

Other courts have struck down antisleeping ordinances. A Florida court held an antisleeping ordinance unconstitutionally vague and overbroad. ${ }^{17}$ In a similar case, the California Supreme Court, using a rational basis analysis, rehed on the equal protection clause to rule unconstitutional a municipal ordinance that prohibited lying on public lawns. ${ }^{18}$

A uniform federal rule on the constitutionality of antisleeping laws is necessary to avoid inconsistent interpretations by state courts. Inconsistent holdings are likely to increase as more cities respond to the lomelessness problem by adopting ordinances that proscribe sleeping in outdoor public areas. Because the homeless must often sleep outdoors, their ability to live in a particular municipahty without the threat of arrest and prosecution will largely depend on state court interpretations of antisleeping laws. A federal rule will prevent states from attempting to avoid the problems of lomelessness by requiring the looneless to live elsewhere.

14. Portland v. Johnson, 59 Or. App. 647, 651-52, 651 P.2d 1384, 1387 (upholding city ordinance prohibiting "camping" in or on any place of general public access), pet. denied, 294 Or. 492, 660 P.2d 681 (1983). See also People v. Davenport, 176 Cal. App. 3d Supp. 10, 12-13, 222 Cal. Rptr. 736, 737 (1985) (upholding a Santa Barbara ordinance prohibiting sleeping in a public street, parking lot, or public area, or in a public park or on a beach between 10:00 p.m. and 6:00 a.m.), cert. denied, 475 U.S. 1141 (1986).

15. Pollard v. State, 687 S.W.2d 373, 374 (Tex. Ct. App. 1985) (court reversed appellant's conviction for violating Dallas antisleeping ordinance because complaint failed to allege culpable mental state as required by state statute and constitution).

16. Seeley v. State, 134 Ariz. 263, 267-68, 655 P.2d 803, 807-08 (Ct. App. 1982). The Seeley court reasoned that because the antisleeping ordinance prohibited only sedentary activities, it encouraged rather than penalized travel. Id. at 266, 655 P.2d at 806. The two defendants were sentenced to sixty and ninety days in jail respectively. Id. at 264,655 P.2d at 805 .

For a discussion of the requirements for a finding of a violation of the right to travel, see infra notes 145-62 and accompanying text.

17. State v. Penley, 276 So. 2d 180, 181 (Fla. Dist. Ct. App. 1973) (ordinance prohibited sleeping upon or in any street, park, wharf, or other public place), cert. denied, 281 So. 2d 504 (Fla. 1984). The court did not address the right to travel issue.

18. Parr v. Municipal Court, 3 Cal. 3d 861, 864, 479 P.2d 353, 355, 92 Cal. Rptr. 153, 155 (1971) (although ordinance was facially neutral, its stated intent was to protect public property from "hippies"), cert. denied, Carmel-By-The-Sea v. Parr, 404 U.S. 869 (1971). The courts in Parr and Penley based their decisions on the United States Constitution and not on their own state constitutions. See id.; Penley, 276 So. 2d at 181. 
This Comment calls for a umform federal rule prohibiting ordinances that proscribe sleeping in all outdoor public areas. After briefly describing the causes of and attempted solutions for homelessness, this Comment argues that broad antisleeping ordinances unconstitutionally burden the fundamental right to travel. Part I summarizes the scope, causes, and symptoms of homelessness. After reviewing the failure to shelter adequately those who have no place to live, it examines the various methods, both benign and belligerent, used by municipalities to remove the homeless from within their borders.

Part II reviews prior attempts to locate the textual source of the constitutional right to travel, argues that this right includes intrastate migration, examines the factors involved when a statute implicates travel, and concludes that laws prohibiting outdoor sleeping in all public areas impinge upon the fundamental right to travel.

Finally, Part III summarizes methods of equal protection analysis and then demonstrates why antisleeping ordinances cannot survive the strict scrutimy review that courts must apply to all laws impinging upon fundamental rights. After arguing that these laws violate the right to travel, this Comment suggests alternatives available to cities concerned with the health and safety issues arising from the presence of a substantial homeless population.

\section{I}

\section{HOMELESSNESS}

This Part reviews the scope, causes, and symptoms of homelessness. It then summarizes the various methods used by municipalities intent on housing or evicting their homeless populations.

\section{A. Scope, Causes, and Symptoms}

\section{Homelessness $^{19}$ has become a national problem of epidemic}

19. "Homelessness" has been defined in many ways. A common definition of a homeless person is one "whose primary nighttime residence is either in the publicly or privately operated shelters or in the streets, in the doorways, train stations and bus terminals, public plazas and parks, subways, abandoned buildings, loading docks and other well hidden sites known only to their users." Note, Building a House of Legal Rights: A Plea for the Homeless, 59 ST. JoHN's L. REV. 530, 530 n.2 (1985) (authored by Maria L. Ciampi) (quoting E. BAXTER \& K. HopPER, Private Lives/Public SPACES: HoMeless AdulTS ON THE STREeTS OF NEW YORK 6-7 (1981)). Other definitions, emphasizing the individual's alienation, define homelessness as a "condition of detachment from society characterized by the absence or attenuation of the affirmative bonds that link settled persons to a network of interconnected social structures." H. BAHR, SKID ROW, AN INTRODUCTION TO DisafFiliation 17 (1973) (quoting Carlow, Bahr \& Sternberg, Homelessness, 6 INT. EnCyClopedia of the Social Sciences, 494 (1968)). See also Note, Homelessness in a Modern Urban Setting, 10 FordhaM URB. L.J. 749, 749 n.1 (1982) (authored by Mark Malone) (citing definition proposed by 25 social service agencies around the nation: "those persons who are unemployed for more than a temporary period of time with no visible means of support and who live 
proportions. ${ }^{20}$ The number of homeless individuals has increased dramatically in the last several years. ${ }^{21}$ Current estimates of the number of homeless people in the Umited States range from a low of $250,000^{22}$ to a high of 3 milhon. ${ }^{23}$ The National Coalition for the Homeless has estimated that there are 90,000 hoineless people in New York alone. ${ }^{24}$ Other large cities also contain significant homeless populations. ${ }^{25}$

In larger cities, many hoineless people still reside in or near skid row areas. ${ }^{26}$ Congregating in such areas allows them to organize themselves into loosely connected groups that can better protect their persons and belongings. ${ }^{27}$ Homelessness, however, is no longer confined to discrete skid row neighborhoods. Fearing poorer, more crime-ridden areas, an increasing number of homeless people choose to live near downtown business districts or in safer residential neighborhoods. Evidence indicates that they migrate to middle-income areas because their conspicuous presence provokes negative reactions from residents of wealthier areas. ${ }^{28}$ The homeless also hive in small cities, suburbs, and rural areas. ${ }^{29}$ Indeed, in smaller cities with temperate climates, the homeless are likely to constitute a significant proportion of the population and thus may be especially noticeable.

The inajor causes of homelessness are well documented. Perhaps the greatest contributor has been the deinstitutionalization of mentally ill

in the streets, abandoned buildings, doorways, transportation facilities, public parks or under bridges"). This Comment adopts the definition focusing on nighttime residence.

20. Note, Homelessness in America: Looking for the Right to Shelter, 19 Colum. J.L. \& Soc. Probs. 305, 305 (1985) (authored by James K. Lawrence III and Mark A. Kass).

21. See infra note 25 .

22. Note, supra note 20, at 305 n.l (citing OFFICE OF POLICY DEV. AND RESEARCH, DEPT. OF Housing AND URBAN DEV., A REPORT TO THE SECRETARY ON THE HoMELESS AND EMERGENCY SHELTERS 19 (1984) (hereinafter "HUD REPORT").

23. Note, Building a House of Legal Rights: A Plea for the Homeless, supra note 19, at $530 \mathrm{n} .1$ (citing Brief for the National Coalition for the Homeless as Amicus Curiae at 3, Clark v. Community for Creative Non-Violence, 468 U.S. 288 (1984) (No. 82-1998)).

24. N.Y. Times, Jan. 26, 1988, at B2, col. 3.

25. In Los Angeles, estimates of the number of homeless people run as high as 50,000. Ropers, The Rise of the New Urban Homeless, 26 PuB. AfF. REP., Oct. 1985, at 1, 3. In 1981, Boston's homeless population was between 4,000 and 8,000, and Washington, D.C.'s was estimated from 5,000 to 10,000. Note, Homelessness in a Modern Urban Setting, supra note 19, at 749 n.3. In 1986, the estimated figure for Washington, D.C. ran as high as 18,000 . M. HoPE \& J. Young, THE FACES OF HOMELESSNESS 65 (1986).

26. See generally S. WAllace, SkID Row AS A WAY OF LIFE (1965) (discussing history, purposes, and characteristies of skid row neighborhoods).

27. Memorandum of Points and Authorities for Plaintiffs at 6, Bennion v. City of Los Angeles (Cal. Super. Ct. filed June 3, 1987) (No. C 637718) (citing declarations of homeless persons).

28. Note, Homelessness in a Modern Urban Setting, supra note 19, at 751 n.5 (citing Beck \& Marden, Street Dwellers, 86 NAT. HIST. 78 (1977)); see also infra notes 58-63 and accompanying text.

29. M. HoPE \& J. YouNG, supra note 25, at 31-35; Note, supra note 20, at 308. 
patients who pose no danger to themselves or others. ${ }^{30}$ Promoters of deinstitutionalization envisioned the establishment of community support systems designed to absorb those released. However, these systems never materialized, leaving many discharged patients without assistance. Often, they quickly become homeless because they lack resources, are unemployable, and are unable to take advantage of low-income housing and other social services available to others. ${ }^{31}$ As a result, the mentally ill, through no fault of their own, constitute a significant percentage of the homeless population. ${ }^{32}$

The general lack of low-income housing is a second major cause of homelessness. ${ }^{33}$ Many homeless people have lost their homes through eviction, landlord abandonment, or condominium conversion. ${ }^{34}$ Because of major cutbacks in federal funding for low-income housing, they are often unable to locate affordable replacement housing. ${ }^{35}$ Homeless people who do not have or cannot turn to family or friends may therefore have no choice but to hive on the streets.

Homelessness also results from inefficiencies and cutbacks in social service and benefit programs. ${ }^{36}$ The very transience of the homeless hinders the creation of coherent welfare programs designed to serve them. ${ }^{37}$ Moreover, the bureaucratic requirements of many benefit programs often freeze out those who do not have permanent or temporary addresses. ${ }^{38}$ Thus, even where help is available, governments have difficulty delivering the services that might enable some recipients to avoid the plight of homelessness. Freezes and reductions in federal funding of these

30. See M. Hope \& J. Young, supra note 25, at 163-66; Note, supra note 20, at 312-13; Note, Homelessness in a Modern Urban Setting, supra note 19, at 763-66. See generally Rhoden, The Limits of Liberty: Deinstitutionalization, Homelessness, and Libertarian Theory, 31 EMORY L.J. 375, 375 (1982) ("[Deinstitutionalization] has meant a nightmare existence in the blighted centers of our cities.") (quoting A. SCULl, Decarceration: Community TREATMENT AND THE DEVIANT: A RADICAL VIEW 2 (1977)); Segal \& Baumohl, Engaging the Disengaged: Proposals on Madness and Vagrancy, 25 SOCIAL WORK 358, 358 (1980).

31. Note, supra note 20, at 313; Note, Homelessness in a Modern Urban Setting, supra note 19, at 763-65.

32. Estimates of the actual percentage of mentally ill homeless people vary widely. Somc estimate that nearly $90 \%$ suffer from some mental problem, whereas others claim the figure is as low as 20\%. See M. HOPE \& J. YounG, supra note 25, at 20-21.

33. See Reid, Law, Politics and The Homeless, 89 W. VA. L. Rev. 114, 139 n.119 (1986). Some claim that the lack of affordable housing is a primary cause of homelessness. See N.Y. Times, Jan. 26, 1988, at B2, col. 3 .

34. M. HOPE \& J. YOUNG, supra note 25 , at 26.

35. Id. at 133-52. 14.

36. Memorandum of Points and Authorities, supra note 27, at 4-5; Note, supra note 20, at 313-

37. Segal \& Baumohl, supra note 30 , at 359 (arguing that benefits are poorly delivered because clients disappear, efforts are duplicated, and funds are spent on inappropriate scrvices).

38. Note, Building a House of Legal Rights: $A$ Plea for the Homeless, supra note 19, at 533-37 \& nn. 32-40. 
programs have aggravated an already difficult sitnation. ${ }^{39}$

A final identifiable cause of homelessness is chronic unemployment. Some of the chronically unemployed lose residences for failure to pay rent; others, repeatedly lured to new areas by the promise of jobs, never acquire permanent housing. ${ }^{40}$ Many of the structurally unemployed and their families must therefore turn to the streets, alleys, parks, and abandoned buildings of the cities and towns to which they migrate.

Because of the diverse causes of homelessness, the stereotype of a street dweller as an older alcoholic male has lost much of its validity. Although soine homeless mdividuals are alcohohics, drug addicts, or mentally ill, ${ }^{41}$ an increasing number suffer from no mental illness or physiological dependencies. Many are impoverished elderly people, runaway children, physically handicapped persons, or female-headed families, each of whom suffer disproportionately from physical abuse and the general lack of support services and low-income housing. ${ }^{42}$ In any case, the overwhelming majority of homeless people are needy and helpless individuals who are not homeless by choice. ${ }^{43}$

\section{B. Attempts to Remove the Homeless from Public Areas}

Local governments ${ }^{44}$ have generally failed to alleviate the homeless-

39. M. Hope \& J. Young, supra note 25 , at 26.

40. Note, supra note 20, at 313. See generally sources cited supra note 30.

41. See M. Hope \& J. Young, supra note 25, at 21-22; Note, supra note 20, at $308 \mathrm{n} .21$. In some public shelters, the most prevalent drug is "crack." See, eg., N.Y. Times, Feb. 18, 1988, at A1, col. 1 .

42. Note, supra note 20 , at 311-12. Because single women with children constitute such a large percentage of benefit program recipients, they have suffered disproportionately from funding cutbacks and delivery difficulties. Holden, Homelessness: Experts Differ on Root Causes, 232 ScI. 569,569 (1986). See supra notes 36-39 and accompanying text.

43. See M. HOPE \& J. YouNG, supra note 25 , at 23 (citing a goverument study that indicated that $38 \%$ of the homeless surveyed had recently been evicted). Because so many homeless people fall into this category, antisleeping laws that implicitly use homelessness as a proxy for potential criminal behavior are vastly "overinclusive" under an equal protection analysis. See generally infra notes 207-25 and accompanying text (discussing equal protection analysis and its application to antisleeping statutes).

44. The federal and state goveruments have also responded to the homelessness crisis. The federal government has focused most of its efforts on providing emergency funding both for public shelters and for more general relief programs. Federal efforts include establishment of the Federal Emergency Management Agency and the Federal Interagency Task Force, as well as continued funding of Aid to Families with Dependent Children, Medicaid, Medicare, Food Stamps, and Supplemental Security Income. See Note, Building a House of Legal Rights: A Plea for the Homeless, supra note 19, at 533-34. The efforts of state governments have similarly focused on providing the homeless with shelter and services. Note, supra note 20, at 322 . State governments have also turned to stricter enforcement of protective service laws. See infra note 56.

Homeless advocates have also been active in attempts to help the homeless locate shelter. Many have engaged in litigation designed to crcate a right to safe and adequate shelter by relying on state general assistance statutes and state constitutional provisions guaranteeing assistance to the poor. These efforts have generally failed, although New York City, under a consent decree entered in 1981, 
ness problem. Their attempts to use shelters ${ }^{45}$ to house the homeless have been sporadic, mcomplete, and largely inadequate. Privately run shelters offer their occupants some privacy and a relatively relaxed atmosphere, ${ }^{46}$ but they can accommodate only a small number of people and are usually filled to capacity. ${ }^{47}$ Smaller, specialized public shelters enforce specific entrance requirements that render them unavailable to most homeless individuals. ${ }^{48}$ Single-occupancy welfare hotels and the larger general-purpose public shelters are often unsafe or overcrowded: ${ }^{49}$ many homeless people choose to sleep in public parks, train stations, abandoned buildings, and streets rather than these shelters ${ }^{50}$ because they fear the theft and violence, ${ }^{51}$ drug addicts, ${ }^{52}$ and unsanitary conditions that pervade the shelters. ${ }^{53}$

In an attempt to counteract the reluctance of its homeless people to enter public slielters, New York City has empowered city authorities to commit homeless individuals wlio refuse to go voluntarily to a city shelter. $^{54}$ Under the program, teams of city workers ${ }^{55}$ search for homeless people and encourage them to enter available pubhic shelters. If a homeless person refuses to enter a shelter, a psychologist conducts an on-the-

has agreed to provide shelter to all who request it. See Callahan v. Carey, No. 42582/79 (N.Y. Sup. Ct. August 26, 1981) (consent decrec); Note, supra note 20, at 334-45.

45. Shelters may be grouped into four types: privately run missions and church-affiliated shelters; smaller, specialized public shelters; single-occupancy welfare hotcls; and large-capacity, dormitory-style public shelters. See M. Hope \& J. Young, supra note 25, at 40-44; N.Y. Times, Jan. 26, 1988, at B1, col. 3.

46. Note, supra note 20 , at 318 .

47. Memorandum of Points and Authorities, supra note 27, at 4, 8; Note, supra note 20, at $317-23$.

48. N.Y. Times, Feb. 18, 1988, at A42, col. 1. Examples of such shelters in New York are those for veterans, the elderly, and those deemed "employable" by shelter organizers. See $i d$.

49. Memorandum of Points and Authorities, supra note 27, at 3, 5.

50. See, e.g., N.Y. Times, Feb. 18, 1988, at 1, col. 1 (indicating that homeless advocates believe many people fear for their lives while in public shelters); N.Y. Times, Feb. 7, 1984, at A26, col. 1 (editorial arguing that those homeless who choose to live on the streets consider shelters very dangerous).

51. Municipal shelters must generally accept all who apply and therefore inevitably house young aggressive men prone to violence. Note, supra note 20 , at 317 n.65.

52. A director of a mental health program at the Fort Washington Armory in New York asserts that as many as $85 \%$ of the Armory's residents may be crack users. N.Y. Times, Feb. 18, 1988, at Al, col. 1 .

53. A mnnicipal report has observed that "[ $[t]$ he New York City Men's Shelter resembles nothing so much as a 19th century insane asylum. A large room off the lobby is filled with over 100 men. Some lie curled up on the dirty floor; a few are in various stages of undress; others gesture wildly in the air talking to themselves. Some just sit staring into space. The stench of urine and unwashed bodies is strong." Rhoden, supra note 30, at 376 (quoting OFFICE of THE PRESIDENT OF the New York City Council, From Country Asylums to City Streets: The Contradiction Between Deinstitutionalization and State Mental Health Funding PRIORITIES 30 (1979)).

54. See generally Note, Building a House of Legal Rights: A Plea for the Homeless, supra note 19, at 543 \& n.77 (describing New York City's application of its Mental Hygiene law).

55. Each team is composed of a police officer, a social worker, and a psychologist. Id. 
spot psychological examination. When the temperature drops below thirty-two degrees, the psychologist may deem any individual who refuses shelter a danger to himself and temporarily commit him to a special "homeless" unit at Bellevue Hospital. ${ }^{56}$ A New York appellate court upheld the constitutionality of the city's policy. ${ }^{57}$

Otlier cities have sliown less tolerance towards the homeless. Intolerance has been exemplified by complaimts from local merchants claiming that their businesses are harmed by tlie presence of tlie homeless, ${ }^{58}$ by cities' desire to prevent the drain on municipal services that often accompanies tlie homeless, ${ }^{59}$ and by negative reactions of local residents to the growing number of homeless people migrating to their communities from skid row areas. ${ }^{60}$ These negative reactions stem from a fear of increased crinie and unsanitary conditions, ${ }^{61}$ a distaste for begging and other hiving habits of the homeless, ${ }^{62}$ and a general desire to avoid those who are honieless. ${ }^{63}$

Some nunicipalities have aggressively sought to drive the homeless out of their jurisdictions. Many cities have strictly enforced zoning ordinances in order to shut down private missions and church-affiliated shelters that are in technical violation of the law. ${ }^{64}$ Less conimon, though more direct, is the intentional creation of health hazards designed to purge cities of their honeless. For example, St. Louis, Missouri and Fort

56. See generally Appellant's Reply Brief, Anonymous v. N.Y.C. Health and Hosp. Corp., 132 A.D.2d 340, 523 N.Y.S.2d 71, appeal dismissed as moot, 70 N.Y.2d 972, 520 N.E.2d 515 (1988).

State governments have also attempted to remove the homeless from the streets by imposing involuntary protective services. Protective service laws allow state officials to detain temporarily homeless individuals who face serious physical harm and are unable to comprehend the danger to themselves. Note, Building a House of Legal Rights: A Plea for the Homeless, supra note 19, at 54041 \& nn. 58, 64; Note, Homelessness in a Modern Urban Setting, supra note 19, at 752 nn. 8-10.

57. Anonymous v. N.Y.C. Health and Hosp. Corp., 132 A.D.2d 340, 523 N.Y.S.2d 71, appeal dismissed as moot, 70 N.Y.2d 972, 520 N.E.2d 515 (1988) (declining to rule on the issue on the grounds that the case was moot because the plaintiff had been released in the interim).

58. See, e.g., supra note 2; L.A. Times, May 30, 1987, pt. I at 1, col. 5; L.A. Times, Sept. 11, 1986, pt. IX, at 4, col. 3 (discussing complaints of area business people).

59. See Memorandum of Points and Authorities, supra note 27, at 4.

60. See infra notes 61-63.

61. See, e.g., L.A. Times, July 27, 1986, pt. IX, at 1, col. 1; L.A. Times, May 30, 1987, pt. I, at 1, col. 5 .

62. See, e.g., N.Y. Times, June 6, 1987, $\S 2$, at 8 , col. 1 .

63. See Fenster v. Leary, 220 N.Y.2d 309, 313, 229 N.E.2d 426, 430 (1967) ("[The vagrants'] main offense usually consists in their leaving the environs of skid row and disturbing by their presence the sensibilities of residents of nicer parts of the community ...." (emphasis in original)).

64. Homelessness TASK ForCe, Homelessness iN AMERICA 27-30 (1986). "Technical" violations include the failure to adhere to building codes which traditionally are not strictly enforced. See, e.g., St. John's Evangelical Lutheran Church v. City of Hoboken, 195 N.J. Sup. 414, 479 A.2d 935 (1983) (city restrained from applying zoning laws to church shelter). Some cities may resort to this method after failing to convince private missions to reloeate. See Note, Building $a$ House of Legal Rights: A Plea for the Homeless, supra note 19, at 544 n.79. 
Lauderdale, Florida have sprayed edible garbage with chlorine. ${ }^{65}$

Historically, authorities have removed transients from the streets by arresting and prosecuting them for violating vagrancy laws. ${ }^{66}$ Until recently, most states enforced laws that punished and often jailed people for their status ${ }^{67}$ as "vagrants". ${ }^{68}$ In 1972, however, the Supreme Court declared vagrancy laws unconstitutionally vague. ${ }^{69}$

Denied vagrancy laws, cities have relied increasingly on loitering laws in order to arrest and prosecute the homeless. ${ }^{70}$ However, loitering laws have also come under constitutional attack: The Supreme Court has held that statutes requiring persons who loiter to provide a requesting police officer with "credible and reliable" identification are unconstitutionally vague, ${ }^{71}$ and federal and state courts have held loitering statutes without such identification provisions to be unconstitutional on vagueness and unreasonableness grounds. ${ }^{72}$ Specific statutes prohibiting loitering only at certain times and in certain places have been upheld more regularly. ${ }^{73}$ State courts, however, have begun to declare these

65. Christian Science Monitor, Jan. 30, 1987, at 3.

66. In 16th-century England, the "Slavery Acts" called for a two-year "enslavement penalty ... for anyone who "liveth idly and loiteringly, by the space of three days'." Note, Homelessness in a Modern Urban Setting, supra note 19, at 754 n.17 (quoting 1 Edw. 6, ch. 3 (1547)). Authorities subjected able-bodied vagrants to such sanctions as whipping, scourging, and bodily humiliation. Id. at 754 n.16 (citing 22 Hen. 8, ch. 12 (1550)). See generally C.J. R1BTON-TURNER, A History OF VAGRANTS AND VAGRANCY AND BEGGARS AND BEGGING (1887).

67. As late as 1956, all American jurisdictions punished the offense of vagrancy. Foote, Vagrancy-Type Law and its Administration, 104 U. PA. L. REv. 603, 609 \& n.7 (1956). In City of New York v. Miln, the Supreme Court found it "necessary for a state to provide precautionary measures against the moral pestilence of paupers [andl vagabonds." City of New York v. Miln, 36 U.S. 102, 142 (1837).

68. At common law a "vagrant" was an idle person without visible means of support who, although able to work, refused to do so. Foote, supra note 67, at 609.

69. Papachristou v. City of Jacksonville, 405 U.S. 156 (1973). The New York Court of Appeals declared its state's vagrancy law unconstitutional on the ground that it exceeded the permissible police powers of the state. Fernster v. Leary, 220 N.Y.2d 309, 229 N.E.2d 426 (1967).

70. See Note, Homelessness in a Modern Urban Setting, supra note 19, at 758-59 (discussing New York's loitering statute). Unlike vagrancy laws, which punish people for their status or appearance, loitering statutes do not include indigence as an element of the offense. Rather, they permit the arrest of individuals whose apparent and unexplained aimlessness engenders the suspicion that they are about to commit a crime. See Note, Building a House of Legal Rights: A Plea for the Homeless, supra note 19 , at 538-40.

71. Kolender v. Lawson, 461 U.S. 352 (1983). The Court has also declared unconstitutional laws that allowed a person to loiter on a public street or sidewalk "only at the whim of any police officer of that city." Shuttlesworth v. Birmingham, 382 U.S. 87, 90 (1965).

72. See, e.g., United States ex rel. Newsome v. Malcolm, 492 F.2d 1166 (2d Cir. 1974) (vagueness), aff'd on other grounds sub nom., Lefkowitz v. Newsome, 420 U.S. 283 (1975); Bulloek v. City of Dallas, 248 Ga. 164, 281 S.E.2d 613 (1981) (unreasonableness and vagueness); Soles v. City of Vidalia, $92 \mathrm{Ga}$. App. 839, 90 S.E.2d 249 (1955) (unreasonableness); City of Akron v. Efland, 112 Ohio App. 15, 174 N.E.2d 285 (1960) (unreasonableness). See generally Note, Orders To Move On and the Prevention of Crime, 87 YALE L.J. 603 (1978) (examining loitering and vagrancy laws).

73. Note, Building a House of Legal Rights: A Plea for the Homeless, supra note 19, at 539; Note, Homelessness in a Modern Urban Setting, supra note 19, at 759 n.42; see, e.g., United States v. 
more limited laws unconstitutional because of the arbitrary power they confer on police. ${ }^{74}$

Because of the constitutional problems inherent in vagrancy and loitering statutes, many cities are using antisleeping ordinances to remove the homeless from their streets and, ultimately, from their jurisdictions. ${ }^{75}$ The enforcement of this new arrest and prosecution tool has exacerbated the plight of the homeless. In Part II, this Comment argues that antisleeping ordinances burden the fundamental right to travel because such laws make it impossible for the homeless to remain in or enter a community that adopts and enforces the ordinances.

\section{II}

\section{The Right to TRAVEL}

This Part shows that antisleeping laws burden the fundamental right to travel. After identifying the right to travel as fundamental, it argues that the right encompasses intrastate migration, the type of travel most likely affected by antisleeping ordmances. It then identifies the factors examined by the Supreme Court to determine whether a law inpinges upon the right, and it concludes that antisleeping laws burden the fundamental right to travel.

\section{A. The Source of the Right To Travel}

Because many homeless people have little access to transportation, their migration usually occurs within a state. ${ }^{76}$ Therefore, for the right to travel to bar enforcement of antisleeping ordinances against all homeless persons, it must protect intrastate as well as interstate migration. Courts and commentators have proposed several clauses in the Constitution as sources for the right to travel. ${ }^{77}$ Not every proposed source, however, allows for the protection of imtrastate migration.

This Section reviews the history, scope, and proposed textual sources of the right to travel. It demonstrates that the restrictive view of the right to travel stemming from several of the proposed sources no

Cassignol, 420 F.2d 868 (4th Cir.) (validating statute prohibiting loitering on a specific piece of government property), cert. denied, 397 U.S. 1044 (1970).

74. For example, the New York Court of Appeals recently ruled unconstitutionally vague a statute banning loitering in major New York transportation centers. People v. Bright, 71 N.Y.2d 376,520 N.E.2d 1355 (1988). The law had been used by police to arrest homeless people who slept in bus and train stations. See id. Though loitering statutes used against the homeless may present constitutional problems, they are beyond the scope of this Comment. This Comment is limited to a constitutional analysis of antisleepiug ordinances.

75. See supra notes $3 \& 5-12$ and accompanying text, and text accompanying note 13 .

76. Of course, some homeless migration will include interstate travel. The protection of such migration does not depend upon a finding that intrastate travel is a fundamental right. See generally infra notes 112-44 and accompauying text.

77. See infra text accompanying notes 87-106. 
longer comports with current Supreme Court doctrine. It therefore concludes that the right must be grounded in either the due process or the equal protection clause, both of which allow for protection of intrastate migration.

The freedom to travel interstate and to settle in a place of one's choosing without governmental interference have long been recognized as basic rights. ${ }^{78}$ Predating the U.S. Constitution, versions of the right to interstate travel appear in the Magna $\mathrm{Carta}^{79}$ and in Blackstone's Commentaries. $^{80}$ The Pennsylvania Constitution of 1776 proclaimed it a "natural and inherent right" itly recognized it. ${ }^{82}$ The right received its earliest judicial recognition in $1823,{ }^{83}$ and was formally noted by the Supreme Court in $1849 .{ }^{84}$

Despite this early recognition, the Supreme Court has never reached a consensus concerning the specific constitutional source of the right to travel. ${ }^{85}$ At times the Court has even suggested that it is a "sourceless" right. ${ }^{86}$ At other times the Court has relied on several constitutional clauses, which, because of changing interpretations of the clauses and of the right to travel itself, can no longer serve as sources for the right.

78. See infra note 86.

79. The Magna Carta guaranteed "free passage into and out of the realm." Comment, $A$ Strict Scrutiny of the Right To Travel, 22 UCLA L. REV. 1129,1129 n.3 (1975) (authored by Stewart Baker) (citing MAGNA CARTA, ch. 42 (1215)); see also Eggert v. City of Seattle, 81 Wash. 2d 840, 841, 505 P.2d 801, 802 (1973).

80. Comment, supra note 79, at 1129 n.3 (citing 1 W. Blackstone, COMmentaries 134).

81. Id. (citing $\mathrm{P}_{\mathrm{A}}$. CONST. OF $1776 \mathrm{ch}$. 1, para. XV).

82. The Articles of Confederation proclaimed a right of "free ingress and regress to and from any other State" ARTiCles Of CONFEderation, art. IV. See also Comment, Intrastate Residence Requirements for Welfare and the Right to Intrastate Travel, 8 HARV. C.R.-C.L. L. REV. 591, 600 \& n.58 (1973) (authored by Mary Fowler); Comment, supra note 79, at 1130 \& n.6; Eggert, 81 Wash. $2 \mathrm{~d}$ at 841,505 P.2d at 802 .

83. Comment, Intrastate Residence Requirements for Welfare and the Right to Intrastate Travel, supra note 82, at 600 n.56 (citing Corfield v. Coryell, 6 F. Cas. 546, 552 (C.C.E.D. Pa. 1823) (No. 3230)).

84. Id. (citing Smith v. Turner, 48 U.S. (7 How.) 282, $491-92$ (1849)).

85. Comment, The Right to Travel: In Search of a Constitutional Source, 55 NEB. L. REv. 117, 117 (1975) (authored by D. Schroeder); see also Comment, supra note 79, at 1140-41 (listing six potential sources of the right to travel: the first amendment, the privileges and immunities clause of article IV, the privileges or immunities clause of the fourteenth amendment, the commerce clause, the due process clause, and the equal protection clause). This Comment argues that the equal protection and due process clauses are the only viable textual sources. See infra notes 100-11 and accompanying text.

86. See Shapiro v. Thompson, 394 U.S. 618, 630 (1969) ("We have no occasion to ascribe the source of this right to travel interstate to a particular constitutional provision."); United States $v$. Guest, 383 U.S. 745, 758-59 (1966) (The right to travel "finds no explicit mention in the Constitution. The reason, it has been suggested, is that a right so elementary was conceived from the beginning to be a necessary concomitant of the stronger Union the Constitution created ....."). Choosing a specific source, however, helps to avoid irresponsible decisionmaking unconstrained by the text of the Constitution or by precedents interpreting that text. Comment, supra note 79, at 1142-43. Identifying a textual source is also necessary to determine the extent of protection provided by the right to travel. Id. 
The privileges and immunities clause of article IV, relied on by the early Supreme Court right-to-travel cases ${ }^{87}$ can no longer serve as the source of the right. ${ }^{88}$ In Ward v. Maryland, ${ }^{89}$ the Court stated that the clause "plaimly and unmistakably secures and protects the right of a citizen of one State to pass into any other State of the Union . . . without molestation." 90 However, in the Slaughter-House Cases ${ }^{91}$ decided the following year, the Court seenred to limit the scope of the clause. ${ }^{92}$ The current view holds that article IV does not protect the right to travel because it merely forbids states from discriminating in favor of their own citizens and has no substantive content of its own. ${ }^{93}$

Neither can the privileges and iminumities clause of the fourteenth amendment nor the interstate commerce clause, two sources subsequently suggested by the Court, ${ }^{94}$ serve as sources for the right to travel. The Court has held that the fourteenth amendment's privileges and imniunities clause guarantees only the rights growing out of national citizenship..$^{95}$ Because the Court has for inany years strictly linited national citizenship rights, ${ }^{96}$ it is unlikely that it would include the right to travel antong thein. Similarly, because right-to-travel jurisprudence forbids the federal governnient from burdening imterstate travel, ${ }^{97}$ it nrakes little sense to base this right on the commerce clause, a provision granting the federal governmient broad powers to regulate interstate cominerce. ${ }^{98}$

87. See, e.g., Ward v. Maryland, 79 U.S. (12 Wall.) 418, 430 (1871); Paul v. Virginia, 75 U.S. (8 Wall.) 168, 180 (1869), overruled, United States v. South-Eastern Underwriters Ass'n, 322 U.S. 533 (1944).

88. See Comment, Intrastate Residence Requirements for Welfare and the Right to Intrastate Travel, supra note 82, at $603 \& \mathrm{nn} .74-75$.

89. 79 U.S. (12 Wall.) 418 (1871).

90. Id. at 430 .

91. 83 U.S. (16 Wall.) 36 (1872).

92. "Its sole purpose was to declare to the several States, that whatever those rights, as you grant ... to your own citizens[ ] . . the same, neither more nor less, shall be the measure of the rights of citizens of other States within your jurisdiction." Id. at 77; see Comment, Intrastate Residence Requirements for Welfare and the Right to Intrastate Travel, supra note 82, at 603.

93. Comment, Intrastate Residence Requirements for Welfare and the Right to Intrastate Travel, supra note 82, at 603-04.

94. See Edwards v. California, 314 U.S. 160, $172-74$ (1941); id. at 179 (Douglas, J., concurring).

95. See Hague v. CIO, 307 U.S. 496,520 (1939) (describing the clause as applying to rights which "grow out of the relationship of United States citizens to the national government.").

96. Sce Slaughter-House Cases, 83 U.S. (16 Wall.) 36 (1873) (listing those few rights traditionally described as rights of national citizenship); Comment, supra note 79, at $1142 \mathrm{n} .70$ (same).

97. See, e.g., Aptheker v. Secretary of State, 378 U.S. 500 (1964); Kent v. Dulles, 357 U.S. 116 (1958).

98. Article I, section 8 provides in part that "The Congress shall have Power ... to regulate Commerce with foreign Nations, and among the several States ...." U.S. CONST. art. I, § 8. This power has been very broadly interpreted for over fifty years. See, eg., NLRB v. Jones \& Laughlin Steel Corp., 301 U.S. 1 (1937) (upholding section of National Labor Relations Act). 
Apparently recognizing this problem, the Court has not relied on the commerce clause as the source of the right to travel for nearly fifty years. $^{99}$

Only two plausible sources remain: the due process clause of the fifth amendment and the equal protection clause of the fourteenth amendment. ${ }^{100}$ The Supreme Court first adopted an equal protection analysis in Shapiro v. Thompson. ${ }^{101}$ The Court noted that the right to travel is a "fundamental" right and held that any classification which "penalize[s]" its exercise is unconstitutional unless shown to be necessary to serve a compelling state interest. ${ }^{102}$ In subsequent cases the Court often either relied upon or recognized the equal protection clause as a potential source of the right to travel. ${ }^{103}$

In Sosna v. Iowa ${ }^{104}$ the Court turned to the due process clause as a source of the right to interstate travel. ${ }^{105}$ The Court upheld a one-year residence requirement for obtaining a divorce after applying a due

99. See Edwards v. California, 314 U.S. 160 (1941). Because the fourteenth amendment's privileges and immunities clause may be inapplicable to the federal government, see Comment, supra note 79, at 1142 n.70; contra Kurland, The Privleges and Immunities Clause: "Its Hour Come Round At Last"?, 1972 WASH. L.Q. 405, 416-19, its use as the source of the right to travel may suffer from an analogous defect.

Yet another previously proposed source for the right to travel, the "penumbra" of the first amendment, see Aptheker v. Secretary of State, 378 U.S. 500, 520 (1964) (Douglas, J., concurring) ("Freedom of movement is kin to the right of assembly and to the right of association"), has been explicitly rejected by the Court. Zemel v. Rusk, 381 U.S. 1, 16 (1965).

100. The due process clause of the fifth amendment provides that "No person shall be . . . deprived of life, liberty, or property, without due process of law ...." U.S. CoNST. amend. V. To determine whether a particular law violates the due process clause, the Supreme Court has applied a balancing test which weighs the individual right implicated by the challenged law against the state interest advanced by the statute. See, e.g., Sosna v. Iowa, 419 U.S. 393, 404-09 (1975).

The equal protection clause of the fourteenth amendment provides that "[n] State shall make or enforce any law which shall ... deny to any person within its jurisdiction the equal protection of the laws." U.S. CONST. amend XIV, $\S 1$. To meet the requirements of the equal protection clause, most social and economic legislation need only be "rationally related to a legitimate state interest." New Orleans v. Dukes, 427 U.S. 297, 303 (1976). However, if the law either implicates a fundamental right or discriminates against a suspect class, the Court will uphold it only if it is necessary to promote a compelling state interest. See Shapiro v. Thompson, 394 U.S. 618, 627, 634 (1969); infra notes 209-12 and accompanying text. Though the equal protection clause technically addresses only the states, it also applies to the federal government through the due process clause of the fifth amendment. See Bolling v. Sharpe, 347 U.S. 497, $498-99$ (1954).

101. 394 U.S. 618 (1969).

102. Id. at 630,634 .

103. See, e.g., Zobel v. Williams, 457 U.S. 55, $66-67$ (1982) (Brennan, J., concurring); Memorial Hosp. v. Maricopa County, 415 U.S. 250, 253-70 (1974); Dunn v. Blumstein, 405 U.S. 330, 335-60 (1972). See generally McCoy, Recent Equal Protection Decisions-Fundamental Right to Travel or "Newcomers" as a Suspect Class?, 28 VAND. L. REv. 987 (1975).

104. 419 U.S. 393 (1975).

105. Id. at 409-10. The Court had previously relied on the due process clause as a source for the right of international travel. See Zemel v. Rusk, 381 U.S. 1, 13-16 (1965); Kent v. Dulles, 357 U.S. 116,125 (1958) ("The right to travel is a part of the 'liberty' of which the citizen cannot be deprived without due process of law ...."). 
process balancing test weighing the individual right to travel against the state interest involved. ${ }^{106}$

In determining whether antisleeping statutes violate the right to travel, it makes little difference whether one relies on the due process or the equal protection clause as its source. Because the right to travel is a fundamental riglit, ${ }^{107}$ a law impinging upon it cannot survive equal protection analysis unless the law is deemed necessary to serve a compelling state interest. ${ }^{108}$ The equal protection clause thus imitially appears to provide greater protection for the right than does the due proces clause. ${ }^{109}$ But, even if the due process clause were used as the source, the fundamental right to travel could not be abridged "absent a slowing of a substantial countervailing state imterest." 110 Indeed, the Supreme Court has stated that the right to travel receives just as mucl protection under a due process analysis as under the equal protection clause. ${ }^{11}$ The next section argues that, whether their source is the due process clause or the equal protection clause, riglit to travel protections extend to intrastate travel.

\section{B. Intrastate Travel as Included in the Fundamental Right to Travel}

Because most hoineless individuals have little access to transportation, ${ }^{112}$ they often inigrate only witlin a single state. Thus, the fundamental right to travel protects inany lomeless people only to the extent that it includes intrastate travel. ${ }^{113}$ This Section argues that logic, notions of personal liberty, commerce clause jurisprudence, and history require the conclusion that the right to travel encompasses intrastate migration.

Althougli the Supreme Court has never ruled on whether the riglit to travel encoinpasses migration which occurs solely within a state, ${ }^{114}$ at

106. Sosna v. Iowa, 419 U.S. at 406-09; see also Bykofsky v. Borough of Middletown, $401 \mathrm{~F}$. Supp. 1242, 1261 (M.D. Pa. 1975), aff'd without op., 535 F.2d 1245 (3d Cir.), cert. denied, 429 U.S. 964 (1976).

107. United States v. Guest, 383 U.S. 745, 757-58 (1966).

108. Shapiro v. Thompson, 394 U.S. 618, 634 (1969).

109. See Attorney General of New York v. Soto-Lopez, 476 U.S. 898, 902 n.2 (1986) ("[T]he right to travel receives its most forceful expression in the context of equal protection analysis.") (quoting Zobel v. Williams, 457 U.S. 55, 67 (1982) (Brennan, J., concurring)).

110. Comment, The Right to Travel: In Search of a Constitutional Source, supra note 85, at 128 \& n.55 (citing Boddie v. Connecticut, 401 U.S. 371 (1971)).

111. See Soto-Lopez, 476 U.S. 898, 904 n.4 (1986) ("Of course, regardless of the label we place on our analysis . . . the standard of review is the same.").

112. Memorandum of Points and Authorities, supra note 27, at 15-16.

113. Again, an antisleeping ordinance that prevents a homeless migrant from traveling interstate could burden the right to travel even if the right did not protect intrastate travel. However, antisleeping ordinances can violate the fundamental right to travel of all homeless migrants only if the right includes intrastate travel.

114. See, e.g., Memorial Hosp. v. Maricopa County, 415 U.S. 250, 255-56 (1974) ("[T]o draw a 
least one Justice has suggested that a fundamental right of intrastate travel does exist. ${ }^{115}$ In nearly all of its travel cases in the last quarter century, however, the Court has characterized the challenged statutes as burdening only interstate travel. ${ }^{116}$ The Court's use of the term "interstate" in its modern travel decisions may, however, be nothing "more than a reflection of the state-wide enactments involved" in those cases, ${ }^{117}$ and thus the use of the word "interstate" should not imply the absence of an intrastate right as well.

Lower courts ${ }^{118}$ and law review articles ${ }^{119}$ have almost uniformly argued that the fundamental right to travel includes intrastate travel. King v. New Rochelle Municipal Housing Authority ${ }^{120}$ represents the leading lower court opinion on this issue. In King, a local government agency required that families reside in New Rochelle, New York for five years before they could apply for state-subsidized public housing. ${ }^{121}$ The King plaintiffs could be divided into two groups: one plaintiff that had recently moved to New Rochelle from North Carolina, and the others that had come from other cities within New York state. Because none of

constitutional distinction between interstate and intrastate travel [is] a question we do not now consider ....").

115. "We are all citizens of the United States; and, as members of the same community, must have the right to pass and repass through every part of it without interruption as freely as in our own States." Smith v. Turner, (Passenger Cases), 48 U.S. (7 How.) 283, 492 (1849) (Taney, C.J., dissenting) (emphasis added).

116. See Attorney General of New York v. Soto-Lopez, 476 U.S. 898 (1986) (employment preference to veterans who were residents of New York state); Zobel v. Williams, 457 U.S. 55 (1982) (state dividend distribution proportioned to length of residence in state); Memorial Hosp. v. Maricopa County, 415 U.S. 250 (1974) (free nonemergency medical care denied to residents of other states); Dunn v. Blumstein, 405 U.S. 330 (1972) (right to vote delayed by state durational residence requirement); Shapiro v. Thompson, 394 U.S. 618 (1969) (right to welfare delayed by state residency waiting period).

117. King v. New Rochelle Mun. Hous. Auth., 442 F.2d 646, 648 (2nd Cir.), cert. denied, 404 U.S. 863 (1971). The Court's failure to determine whether the Constitution protects intrastate travel may simply be the result of its refusal to grant certiorari on questions regarding statutes that impinge on such travel. In any event, the Court has never stated that the right to travel does not encompass intrastate travel.

118. See, e.g., King, 442 F.2d 646; Bykofsky v. Borough of Middletown, 401 F. Supp. 1242 (M.D. Pa. 1975), aff'd without op., 535 F.2d 1245 (3d Cir.), cert. denied, 429 U.S. 964 (1976); Stoner v. Miller, 377 F. Supp. 177 (E.D.N.Y. 1974); Eggert v. City of Seattle, 81 Wash. 2d 840, 505 P.2d 801 (1973); see also Donnelly v. City of Manchester, 111 N.H. 50, 51, 274 A.2d 789, 791 (1971) ("The right of every citizen to live where he chooses and to travel freely not only within the state but across its borders is a fundamental right which is guaranteed by both our own and the Federal Constitutions.").

119. See, e.g., Comment, Keeping the Home Team at Home, 74 CAlIf. L. Rev. 1329, 1353 (1986) (authored by Charles Gray) ("The Supreme Court would likely agree with [the lower courts] were it to consider the [intrastate travel] issue"); Comment, supra note 79, at 1145-46 (arguing that the failure to include intrastate travel in the fundamental right to travel would produce irrational results); Comment, Intrastate Residence Requirements for Welfare and the Right to Intrastate Travel, supra note 82 , at $608-11$.

120. 442 F.2d 646 (2nd Cir.), cert. denied, 404 U.S. 863 (1971).

121. Id. at 647 . 
the plaintiffs had resided in New Rochelle for five years or more, the housing authority denied their apphications for public housing. ${ }^{122}$ The Second Circuit defined the right to travel to include intrastate travel, and held that the regulation's durational residence requirement violated the rights of both the interstate and intrastate plaintiffs. ${ }^{123}$ Thus, the court required that both groups of plaintiffs be permitted to apply for the housing.

King based its holding on the premise that according fundamental right status to interstate, but not intrastate, travel could easily lead to arbitrary and even absurd results. Because the state of New York subsidized the housing project, those plaintiffs who were long-time residents of New York State, albeit from other cities in the state, logically should have had preference over the plaintiffs who imgrated from out of state. ${ }^{124}$ Yet, if intrastate travel were not included in the fundamental right to travel, the regulation would have been unconstitutional ouly as apphed to the former resident of North Carolina (the interstate migrant), and thus only she could have apphed for the housing. The New York plaintiffs (the intrastate migrants) would not have been entitled to apply for housing because their fundainental rights would not have been inphcated. Such a result would be illogical.

Furthermore, intrastate travel should be included in the constitutional right to travel because it represents a substantial part of the personal liberty of "freedom of movement." The Court's decisions striking down vagrancy and loitering laws ${ }^{125}$ and its dicta in right-to-travel cases ${ }^{126}$ both recognize the right of freedom of movement. The present overriding goal of the right to travel is not to advance the concept of federalism or to promote an integrated economy, but rather to protect

122. Id.

123. Id. at $648-49$.

124. Id. See also Memorial Hosp. v. Maricopa County, 415 U.S. 250, 256 n.9 (1974) (applying same rationale to a county residence requirement for free nonemergency medical care).

125. See, e.g., Papachristou v. United States, 405 U.S. 156 (1972):

Persons 'wandering or strolling' from place to place have been extolled by Walt Whitman and Vachel Lindsay....

....

... [T]hese activities are historically part of the amenities of life as we have known them. They are not mentioned in the Constitution or in the Bill of Rights. These unwritten amenities have been in part responsible for giving our people the feeling of independence and self-confidence, the feeling of creativity. These amenities have dignified the right of dissent and have honored the right to be nonconformists and the right to defy submissiveness. They have encouraged lives of high spirits rather than hushed, suffocating silence.

Id. at 164 .

126. See Kent v. Dulles, 357 U.S. 116, 126 (1958) ("Freedom of movement is basic in our scheme of values."); see also Aptheker v. Secretary of State, 378 U.S. 500, 505-06 (1964) (quoting Kent with approval). But cf. Regan v. Wald, 468 U.S. 222, 241 (1984) (criticizing Kent for its failure to distinguish between interstate and international travel). 
the right to migrate. ${ }^{127}$ The protection of this right-an attribute of individual liberty "as close to the heart of the individual as the choice of what he eats, or wears, or reads"128 - should not depend on the crossing of state lines. ${ }^{129}$

Moreover, by analogy to the Court's interstate commerce clause jurisprudence, the right to travel should include intrastate migration. After initially limiting Congress' regulatory authority to those transactions directly related to interstate commerce, ${ }^{130}$ the Court recognized that some Congressional control over intrastate transactions is essential if Congress is to regulate interstate commerce fully and adequately. ${ }^{131}$ Similarly, it may well be necessary to extend the right to travel to intrastate migration in order fully to protect interstate travel. A statute or ordinance that facially does not impinge upon interstate migration nevertheless could effectively limit it by strictly regulating travel within that government's jurisdiction. ${ }^{132}$

A history-based analysis also leads to the conclusion that inovement within a state is a fundamental right. The United States is a country of immigrants, and many of its citizens' values were developed during the nation's western expansion. ${ }^{133}$ Freedoin of moveinent both within and across frontiers is part of our nation's heritage: ${ }^{134}$ "Our nation has thrived on the principle that ... every American is left to shape his own life as he thinks best, do what he pleases, go where he pleases."135

Federalists may argue that extending the right to include intrastate travel would go beyond the right's initial purpose. This argument rests largely on nineteenth-century Supreme Court decisions focusing on the rights of citizens entering, passing through, or leaving a state. The language used in those cases suggests that travel rights are necessary only to ensure that individual states do not harn the nation as a whole by econoinically isolating themselves, ${ }^{136}$ and thus that these rights need not encoinpass intrastate migration.

This argument is easily refuted. First, its reasoning suggests that the

127. L. Tribe, American Constitutional LaW § 15-14, at 1378-79 (2d ed. 1988).

128. Kent, 357 U.S. at 126.

129. See Eggert v. City of Seattle, 81 Wash. 2d 840, 845, 505 P.2d 801, 804 (1973).

130. See United States v. E.C. Knight Co., 156 U.S. 1 (1895).

131. See Wickard v. Filburn, 317 U.S. 111 (1942).

132. Comment, Intrastate Residence Requirements for Welfare and the Right to Intrastate Travel, supra note 82, at 608.

133. Comment, supra note 79 , at 1129.

134. Kent v. Dulles, 357 U.S. 116, 126 (1958).

135. Z. Chafee, Three Human Rights in the Constitution of 1787, at 197 (1956) (emphasis added).

136. See, e.g., Smith v. Turner (Passenger Cases), 48 U.S. (7 How.) 283, 492 (1849) (Taney, C.J., dissenting) ("[I]t intended to secure the freest intercourse between the citizens of the different States. ... [W]e are one people, with one common country."). 
right to travel is actually grounded in the interstate commerce clause, ${ }^{137}$ a view rejected by most commentators ${ }^{138}$ and not advanced by the Court since $1941 .^{139}$ The due process and equal protection clauses, the sources of the right to travel on which the Court has recently relied, ${ }^{140}$ do not require the crossing of a state line to trigger their protections. Indeed, even if the right to travel were based on the notion of the need for unimpeded commerce, the Court's commerce clause jurisprudence recognizes that intrastate activities can substantially affect interstate conımerce. ${ }^{141}$ Also, the federahists' commerce clause-based argument assumes that the right is not protected against federal circumscription because the federal government is free to regulate commerce between the states. ${ }^{142}$ Such a conclusion contradicts Court precedent. ${ }^{143}$

Finally, to include intrastate travel in the fundamental right to travel comports with common sense. No court would uphold a local law that prohibited residents of one county or city from migrating to another county or city in the same state. One's constitutional right to migrate cannot logically depend on so arbitrary an issue as crossing a state line, but rather must extend to travel anywhere within the Umited States. As the Second Circuit recognized in King: "It would be meaningless to describe the right to travel between states as a fundamental precept of personal liberty and not to acknowledge a correlative constitutional right to travel within a state."144

Thus, including intrastate migration in the fundamental right to travel prevents illogical and arbitrary results, helps protect personal freedom of movement, is consistent with analogous Supreme Court jurisprudence, and comports with history and conımon sense. Having established that laws may impinge upon the fundamental right to travel if they burden those who travel solely within a state, this Comment now examines the factors considered when evaluating whether a law "burdens" the right to travel.

137. The interstate commerce clause was adopted primarily because of states' harmful treatment of each other in trade matters. See Stern, That Commerce Which Concerns More States Than One, 47 HaRv. L. REv. 1335, 1337 (1934) (describing reasons for adoption of interstate commerce clause).

138. See, e.g., Comment, The Right to Travel: In Search of a Constitutional Source, supra note 85 , at $120-21$.

139. See Edwards v. California, 314 U.S. 160 (1941). Edwards was the last opinion to use commerce clause analysis to invalidate a statute that burdened the right to travel. See infra notes $146-49$ and accompanying text.

140. See supra notes $100-11$ and accompanying text.

141. See NLRB v. Jones \& Laughlin Steel Corp., 301 U.S. 1, 37 (1937); supra notes 131-32 and accompanying text.

142. See supra note 97.

143. See supra note 98 and accompanying text.

144. King v. New Rochelle Mun. Hous. Auth., 442 F.2d 646, 648 (2d Cir.), cert. denied, 404 U.S. 863 (1971). 


\section{Burdens on the Fundamental Right to Travel}

A statute or ordinance that "burdens" the right to travel is constitutional only if it is found necessary to serve a compelling state interest. ${ }^{145}$ In determining whether antisleeping ordinances "burden" the right to travel intrastate, one must examine the various ways in which the Court has found that statutes impinge upon the right. The Court has found four ways in which statutes can burden travel: by erecting an actual barrier to travel, by intending to deter it, by indirectly penalizing it, and by actually deterring it.

In Edwards v. California, ${ }^{146}$ the Court considered a law that erected an actual barrier to migration. In Edwards, the defendant was convicted of bringing into California an "indigent" who was not a resident of the state. The Court unanimously ruled unconstitutional California's attempt "to isolate itself from difficulties common to all [states] by restrainimg the transportation of persons and property across its borders." 147 Though the majority opinion relied exclusively on the commerce clause, four concurring Justices focused on the individual indigent's right to travel and declared that such direct barriers to travel are impermissible. ${ }^{148}$ Their statement that laws that erect actual barriers to travel violate the right to migrate has since been adopted by the Court. ${ }^{149}$

A law that primarily intends to impede travel also burdens the right to travel. In Zobel v. Williams, ${ }^{150}$ the state of Alaska distributed excess income to its citizens in proportion to their length of residence in the state. ${ }^{151}$ The distribution system was designed both to reward citizens in proportion to their past contributions to the state and to reduce the state's "population turnover." 152 The Court found the former objective constitutionally impermissible, and ruled that the latter purpose, if interpreted as an attempt to inhibit migration, would impermissibly burden the right to travel. ${ }^{153}$

145. Shapiro v. Thompson, 394 U.S. 618,634 (1969). See generally supra note 100 \& infra note 210 (summarizing Supreme Court equal protection analyses).

146. 314 U.S. 160 (1941).

147. Id. at 173.

148. Id. at 177-86. For example, Justice Douglas stated in his concurrence that it "would prevent a citizen because he was poor from seeking new horizons in other states. It might thus with hold from large segments of our people that mobility which is basic to any guarantee of freedom of opportunity." Id. at 181.

149. See, e.g., Zobel v. Williams, 457 U.S. 55,60 n.6 (1982) ("[The right to travel] protect[s] persons against the erection of actual barriers to interstate movement.").

150. 457 U.S. 55 (1982).

151. Id. at 57.

152. Id. at $61 \&$ n.7.

153. See id. at 62 n.9. See also Attorney General of New York v. Soto-Lopez, 476 U.S. 898, 903 (1986); Shapiro, 394 U.S. at 629. 
A law may impinge upon the right to travel even when it only indirectly penalizes migration. In Shapiro v. Thompson, ${ }^{154}$ the Court held unlawful a statute which "denie[d] welfare benefits to otherwise eligible applicants solely because they have recently moved into the jurisdiction," 155 and it ruled that "any classification which serves to penalize the exercise of [the right to travel], unless shown to be necessary to promote a compelling governmental interest, is unconstitutional."156 The Court later emphasized that it is more likely to characterize a law as a "penalty" when it denies the affected party a "basic necessity of life": "[M]edical care is ... 'a basic necessity of life' to an indigent ... . And, governmental privileges or benefits necessary to basic sustenance have often been viewed as being of greater constitutional significance than less essential forms of governmental entitlements."157

A law that actually deters travel burdens the fundamental right to travel. In Memorial Hospital v. Maricopa County, ${ }^{158}$ the Court ruled unconstitutional an Arizona statute which conditioned the receipt of free nonemergency medical care on residence in a county for one year. ${ }^{159}$ The Court condemned the one-year residency requirement because it constituted a penalty on migration and it actually deterred travel. Though it emphasized that actual deterrence is not necessary to trigger a right to travel analysis, ${ }^{160}$ the Court noted that "[a] person afflicted with a serious respiratory ailment, particularly an indigent[,] . . may hesitate [to migrate] if he knows that he must make the move without the possibility of falling back on the State for medical care."161 The Court has not delimited the level of deterrence necessary to impinge upon travel, but at least one lower court has stated that any level of deterrence is

154. 394 U.S. 618 (1969) (holding a one year durational residency requirement for welfare benefit eligibility unlawful).

155. Id. at 634 (emphasis added).

156. Id. (emphasis added; original emphasis deleted). In his concurrence, Justice Stewart wrote of an even stronger right to travel, calling it a "virtually unconditional personal right.". Id. at 643 (Stewart, J., concurring). See also Soto-Lopez, 476 U.S. at 903; Dunn v. Blumstein, 405 U.S. 330, 340 (1972).

157. Memorial Hosp. v. Maricopa County, 415 U.S. 250, 259 (1974) (emphasis added). Commentators have noted the right to travel's frequent nexus with indigency. See, e.g., Comment, supra note 79 , at 1132 n. 23 \& at $1154-55$.

For a discussion of the relationship between the prohibition against outdoor sleeping and the denial of government entitlements, see infra notes 186-88 and accompanying text.

158. 415 U.S. 250 (1974).

159. Id. at 252 .

160. Id. at $257-58$.

161. Id. at 257; see also Attorney General of New York v. Soto-Lopez, 476 U.S. 848, 903 (1986) ("A state law implicates the right to travel when it actually deters such travel ...."); Shapiro, 394 U.S. at 629 ("An indigent who desires to migrate, resettle, find a new job, and start a new life will doubtless hesitate ...."). 
sufficient. ${ }^{162}$

The fundamental right to travel includes intrastate travel, and this right is burdened when a law erects direct barriers to travel, aims primarily to impede travel, imposes an indirect "penalty" on those who exercise their right to migrate, or actually deters travel. ${ }^{163}$ This Comment now shows how ordinances that proscribe outdoor sleeping in all public areas unconstitutionally burden the fundamental right to travel.

\section{The Burden of Antisleeping Ordinances: Application of the Court's Right-To-Travel Analyses to Antisleeping Ordinances}

Antisleeping ordinances burden the right to travel because they erect direct barriers to travel, they are intended to impede travel, and they penalize migration. This Section discusses each of these factors.

\section{Antisleeping Ordinances Erect A Direct Barrier to Travel}

In jurisdictions where no available ${ }^{164}$ shelter exists, ordinances that prohibit overnight sleeping in all public areas ${ }^{165}$ burden travel because their primary effects and objectives ${ }^{166}$ are to ban the in-migration of homeless people and to force out those homeless people already in the jurisdiction. ${ }^{167}$ The homeless who live in such a jurisdiction face a "Hobson's choice": ${ }^{168}$ they must exclude themselves from the jurisdiction or

162. Cole v. Housing Auth., 435 F.2d 807, 810 (1st Cir. 1970) ("[T]he impingement on the right to travel does not have to rise to a fixed level of deterrence.").

163. In all of the Supreme Court cases described in this section, the challenged laws facially discriminated against recent migrants or, in the case of Edwards, 314 U.S. 160, against those who help them migrate. The lack of facial discrimination, however, should not affect the right to travel analysis. See infra notes 191-201 and accompanying text (discussing irrelevance of absence of facial discrimination in antisleeping laws).

164. This Comment does not define "available" shelter as any shelter in the jurisdiction where there happens to be an available bed. To be truly "available" to a homeless person, a shelter must be accessible: either it must be within a reasonable walking distance of a person who must likely carry all of her belongings, or it must be serviced by free transportation. See generally Memorandum of Points and Authorities, supra note 27, at 14-16. A theoretically available yet inaccessible shelter does not change the "barrier" effect of an antisleeping law.

165. This Comment does not address the constitutionality of less comprehensive antisleeping laws. However, it is worthwhile to note that an antisleeping ordinance that prohibits sleeping only in certain areas does not have the effect of banning the in-migration of homeless people. The Court has upheld one such regulation. See supra note 8 (discussing regulations prohibiting sleeping in Washington, D.C.'s parks).

166. Antisleeping laws may have other purposes as well. See infra notes 213-23 and accompanying text. The presence of other purposes, however, does not affect the resulting burden on travel. See generally supra notes 146-63 and accompanying text (discussing ways in which a statute can unconstitutionally burden the right to travel).

167. For a discussion of the constitutionality of a law forcing the homeless out of a jurisdiction, see infra notes 194-201 and accompanying text.

168. One anecdote relates that in the 17th century Thomas Hobson maintained horses to hire and required his customers to take the one ncarest the door. Thus, despite appearances, the customers in reality had no choice. 
face arrest and prosecution for violating its antisleeping ordinance. ${ }^{169} \mathrm{~A}$ migrant homeless person will violate her municipality's antisleeping ordinance whenever she succumbs to her need for sleep. This barrier effectively prevents her from entering the jurisdiction for longer than she can remain awake.

Indeed, the barrier to in-migration created by antisleeping laws exceeds the one deemed impermissible in Edwards. In that case, the law punished the person who brought the indigent migrant into the jurisdiction, whereas antisleeping laws threaten to punish the migrant himself. A law like that in Edwards will not deter the in-migration of those who can enter the jurisdiction without the help of others, whereas an antisleeping statute creates a barrier against the entry of all homeless people. The erection of this direct barrier constitutes a "burden" on the right to travel.

\section{The Primary Objective of Antisleeping Ordinances Is to Impede Travel}

Antisleeping laws burden travel because they primarily seek to discourage the homeless from moving into or remaining in the legislating jurisdiction. ${ }^{170}$ No court has yet ruled on the right-to-travel imphications of antisleeping ordinances' exclusionary objectives, but, in addressing the constitutionality of zoning laws, lower courts have found that laws which seek to impede migration burden the right to travel.

For example, one court has reasoned that the right to travel is violated by "any and all features of [a zoning] plan which, directly or indirectly, seek to control" migration. In Construction Industry Association v. City of Petaluma, ${ }^{171}$ a city adopted a zoning ordinance limiting new hoine construction. Because the ordinance had the "express purpose and the intended and actual effects of . . . exclud[ing] substantial numbers of people who would otherwise have elected to immigrate into the city," it burdened the right to travel. ${ }^{172}$ The court explicitly stated that its holding covered qualitative as well as quantitative controls on migration:

169. Though little empirical data is available on the subject, this Comment assumes that municipalities that enforce antisleeping ordinances are generally unreceptive to their homeless population and therefore unlikely to devote their scarce resources to provide a sufficient number of beds to house those without shelter. For example, Santa Barbara, California, a city which previously enforced an antisleeping ordinance, provides no public shelters for its homeless population.

170. See infra note 181 and accompanying text (describing exclusionary purpose of various antisleeping ordinances); see also Zobel v. Williams, 457 U.S. 55 (1982) (holding that objective of reducing "population turnover" causes statute to burden travel).

171. 375 F. Supp. 574 (N.D. Cal. 1974), rev'd on other grounds, 522 F.2d 897 (9th Cir. 1975), cert. denied, 424 U.S. 934 (1976). The Ninth Circuit did not reach the merits of the right-to-travel issue because it held that the plaintiffs lacked standing to assert a right-to-travel violation. $I d$. at 904-05.

172. Id. at 581 . 
"[The] holding is intended to encompass, not only the outright numerical limitations[,]" but also all aspects of the zoning plan that "seek to control" in-migration. ${ }^{173}$ The court further explained why ordinances designed to be exclusionary burden the right to travel:

The question posed is whether the township can stand in the way of the natural forces which send [our] ... population ... in search of a comfortable place to live. We have concluded not. A zoning ordinance whose primary purpose is to prevent the entrance of newcomers in order to avoid future burdens, economic or otherwise, ... cannot be held valid ....

$\ldots$

... It is not for any given township to say who may or may not live within its confines .... ${ }^{174}$

Under this reasoning, any ordinance designed to exclude people from a jurisdiction may be constitutionally suspect. ${ }^{175}$

Emphasizing the constitutional importance of a law's objective, the Supreme Court has found a zoning ordinance constitutional because it was not aimed at transients. In Village of Belle Terre $v$. Boraas, ${ }^{176}$ a town adopted a zoning ordinance that limited to two the number of unrelated persons who could live in any one household. ${ }^{177}$ Applying a rational basis test, the Supreme Court rejected the plaintiff's right-to-travel challenge and upheld the law because it was a reasonable zoning regulation not aimed at transients. ${ }^{178}$ Because any law regulating conduct may cause someone not to move to a jurisdiction, the Court likely wished to avoid a situation where right-to-travel challenges would succeed merely because a local ordinance restricting certain conduct had the incidental

173. Id. at 586 (emphasis added).

174. Id. at 585-86 (quoting National Land and Inv. Co. v. Easttown Township. Bd. of Adjustment, $419 \mathrm{~Pa}$. 504, 532, 215 A.2d 597, 612 (1965) \& Appeal of Kit-Mar Builders, $439 \mathrm{~Pa}$. 466, 474, 268 A.2d 765, 768-69 (1970)); see also Edwards v. California, 314 U.S. at 183 (Jackson, J., concurring) ("It]hat choice of residence was subject to local approval is contrary to the inescapable implications of the westward movement of our civilization"); Appeal of Girsh, 437 Pa. 237, 263 A.2d 395 (1970) (zoning scheme's failure to provide for apartments excludes those who would be able to live in the township if apartments were available).

175. The Ninth Circuit in Petaluma, 522 F.2d 897 (1985), held that plaintiffs construction industry association and landowners did not have standing to assert a right to travel violation, $i d$. at 904-05, and that the challenged ordinance did not violate the due process or commerce clauses. Id. at 908-09. Because the court dismissed the right to travel claim for lack of standing, it did not rule on the merits of the issue. Id. at $906 \mathrm{n} .13$. However, in dicta the court did note that the law did "not have the undesirable effect of walling out any particular income class." Id. at 908; see also id. at $906 \mathrm{n} .13$ ("[W]e note that the Petaluma Plan is not aimed at transients."). Thus, if faced with a right to travel claim from a plaintiff with standing, the court may well react differently to an ordinance which attempts to evict the homeless population from a jurisdiction.

176. 416 U.S. I (1974).

177. Id. at 2 .

178. Id. at 7-8. By "transients" the Court was referring not to the homeless but rather to people that move to a new residence. 
effect of discouraging some person's migration to a commumity. ${ }^{179}$

This concern, however, is not an issue $\mathrm{m}$ antisleeping laws. Unlike the zoning law in Belle-Terre, ordinances that proscribe public sleeping seem to be aimed at homeless "transients" and not at the act of public sleeping: It is extremely unlikely that a community would choose to prohibit sleeping because of any evil associated with the conduct itself. Moreover, expressions of group antagonism have traditionally provided strong evidence of legislative purpose, ${ }^{180}$ and, not surprisingly, a review of attitudes in cities that enforce antisleeping ordinances indicates that concerns regarding the homeless are the primary motivating force behind the laws. ${ }^{181}$ In addition, even without documentary evidence of such motivation, courts can infer evidence of purpose from the overwhelmingly disproportionate effect such laws have on the homeless. ${ }^{182}$ Because few people who have access to safe, sanitary shelter regularly sleep in outdoor public areas, the vast majority of those arrested are homeless.

Antisleeping ordinances disproportionately affect the hoineless in yet another way: by proscribing conduct vital to their survival, they effectively evict the homeless. Unlike a zoning ordinance that causes a person to choose not to migrate to a city merely because she prefers a different lifestyle, an antisleeping ordinance leaves a homeless individual with no choice. Because she inust sleep outdoors or not at all, a statute

179. See L. TR1BE, supra note 127, at 1381. Tribe has used this reasoning in citing Belle Terre with approval: "The Court was . . entirely correct to reject the right-to-travel challenge in [BelleTerre]." Id. at 1381 n.20.

180. Note, Impermissible Purposes and the Equal Protection Clause, 86 ColuM. L. REv. 1184, 1207 (1986).

181. See, e.g., Memorandum of Points and Authorities, supra note 27, at 7 (stating that the one and only target of Los Angeles' antisleeping law is the homeless); L.A. Times, supra note 11, at col. 3 (antisleeping legislation proposed by Long Beach in 1986 would have "target[ed] vagrants who have long been a problem downtown and elsewhere in the city."); L.A. Times, supra note 12 (quoting a Glendale, California city attorney as stating that the city's once-proposed antisleeping law was "aimed at pushing transients out of town"). See generally supra notes 58-75 and accompanying text (discussing motivations behind antisleeping ordinances and other attempts to remove the homeless from the streets).

182. See Village of Arlington Heights v. Metropolitan Hous. Dev. Corp., 429 U.S. 252, 266 (1977) (stating that "[t]he impact of the [law] may provide an important starting point" in determining the existence of a discriminatory purpose).

The California Supreme Court has recognized the importance of looking beyond facially neutral language in order to acknowledige a law's true, though unstated, purpose:

[W] cannot shut our eyes to matters of public notoriety and general cognizance. When we take our seats on the bench we are not struck with blindness, and forbidden to know as judges what we see as men; and where an ordinance, though general in its terms, only operates upon a special race, sect or class, it being universally understood that it is to be enforced only against that race, sect or class, we may justly conclude that it was the intention of the body adopting it that it should only have such operation, and treat it accordingly.

Parr v. Municipal Court, 3 Cal.3d 861, 866, 479 P.2d 353, 356, 92 Cal. Rptr. 153, 156 (1971) (quoting Ho Ah Kow v. Nunan, 12 F. Cas. 252, 255 (C.C.D. Cal. 1879) (No. 6,546)), cert. denied, 404 U.S. 869 (1971). 
prohibiting such conduct effectively prevents her from living in the jurisdiction. ${ }^{183}$ Antisleeping laws' purposefully exclusionary effect and their extreme disproportionate impact on the homeless clearly distinguish them from traditional zoning laws that have only incidental effects on migration.

Because their primary objectives are to impede homeless in-migration and to evict current homeless residents from the jurisdiction, antisleeping laws burden the right to travel. Because antisleeping laws proscribe an essential human activity, declaring such laws to be a burden on travel will not prevent municipalities with constitutionally valid objectives from enacting laws that regulate nonvital human conduct that may incidentally discourage migration.

\section{Antisleeping Laws Penalize Migration}

Most of the Court's right-to-travel jurisprudence has focused on "penalty analysis." Under this analysis, a law burdens the right to travel if it "penalizes" migration. ${ }^{184}$ The Court has been more willing to find that a "penalty" implicates the right to travel when the challenged law deprives a migrant of a "necessity of life."185 The Court has defined "necessities of life" to include welfare for imdigents ${ }^{186}$ and free nonemergency medical care. ${ }^{187}$

The burdens caused by antisleeping laws implicate the same concerns as those caused by the denial of welfare and medical care. Sleep, although not a government entitlement, is a basic necessity of life, arguably even more basic than welfare for the indigent or nonemergency medical care for the sick. Like the other recognized necessities, sleep for the weary involves "the immediate and pressing need for preservation of life

183. This analysis assumes the absence of accessible shelter within the jurisdiction. See supra note 164 .

Even if shelter beds are accessible, it can be argued that homeless people still are offered no real choice if, as is likely, the shelter is dangerous, drug-infested, crime-ridden, or especially unsanitary. See generally supra notes 45-53 and accompanying text (discussing conditions of public shelters). Giving one the option of sleeping in a place where one's health and possessions are seriously endangered provides no more choice than does the option of arrest and prosecution.

184. See supra notes 154-57 and accompanying text (discussing the Court's use of penalty analysis).

185. See, e.g., Memorial Hosp. v. Maricopa County, 415 U.S. 250, 259 (1973); see also supra notes 154-57 and accompanying text.

186. Shapiro v. Thompson, 394 U.S. 618 (1969). In Shapiro, the Court ruled that a one-year residency requirement for welfare benefits burdened travel because it denied benefits solely on the basis of the hopeful recipient's recent move into the jurisdiction. Id. at 634. See also supra notes $154-56$.

187. Memorial Hosp., 415 U.S. at 259. In Memorial Hospital, the Court applied the rationale used in Shapiro to a law denying nonemergency medical care to recent migrants. Id. 
and health."188 Indeed, imposing a criminal sanction can be a much more severe penalty than withholding a governmental benefit.

Soine commentators have argued that a right-to-travel analysis should be applied only when a law exphcitly discriminates against migrants. ${ }^{189}$ They argue that antisleeping laws do not burden travel because, unlike other laws that the Court has held to implicate travel, ${ }^{190}$ they do not facially discriminate against recent migrants.

This arguinent is flawed because it iguores the disproportionate penalties and exclusionary effects that antisleeping laws inflict on the homeless. The Supreme Court, realizing the potentially disproportionate impact of analogous laws, has recognized that loitering and vagrancy laws implicate the right to travel even though they do not facially discriminate against imigrants. ${ }^{191}$ Though on its face a law that prohibits outdoor public sleeping seems to treat hoineowners, tenants, and homeless people alike, its imipact falls almost exclusively on homeless migrants-the group that must sleep outdoors in public. Few people fortunate enough to have a roof over their heads will be prosecuted under these ordinances-especially because these people are not the targets of the law. ${ }^{192}$

A facial discrimination requirement would allow a mumcipality to create residency standards that certain "undesirable" groups could not meet, thus effectively evicting thein from its jurisdiction. Because a homeless person has no ability to adhere to an antisleeping ordinance, a inunicipality that adopts such a "facially neutral" law in effect forces him to leave the jurisdiction. Indeed, nothing would prevent the municipality from adopting a more comprehensive law which would remove an even broader class of persons already hiving within its borders. ${ }^{193}$

One court has recognized the potential problem of an ordinance with similar unreasonable effects. In Stoner $v$. Miller ${ }^{194}$ the court considered the constitutionality of a Long Beach, New York boarding house

188. Id. at 260, n.15 (quoting Starns v. Malkerson, 326 F. Supp. 234, 238 (D. Minn. 1970), aff'd, 401 U.S. 985 (1971)) (emphasis omitted).

189. See, e.g., Comment, supra note 79, at 1138-39 \& n.55 ("a discriminatory classification based on travel is a prerequisite to strict scrutiny") (emphasis omitted).

190. See, e.g., Zobel v. Williams, 457 U.S. 55 (1982) (length of residence used to determine citizens' share of state income); Shapiro v. Thompson, 394 U.S. 618 (1969) (length of residence used to determine eligibility for welfare).

191. See Kolender v. Lawson, 461 U.S. 352, 358 (1983) (California's loitering law "implicates consideration of the constitutional right to freedom of movement"); see also Papachristou v. City of Jacksonville, 405 U.S. 156 (1972).

192. See supra notes $180-82$ and accompanying text (discussing apparent purpose of antisleeping ordinances).

193. Of course, such a law would have to have some "rational basis" in order to survive equal protection analysis. See infra note 210 .

194. 377 F. Supp. 177 (E.D.N.Y. 1974). 
ordinance which prohibited the registration of those who required "continuous medical or psychiatric services." 195 The plaintiffs, patients awaiting release from a state mental hospital, had no alternative to residing in a boarding house if they wished to remain in Long Beach. ${ }^{196}$ The ordinance effectively forced the plaintiffs to leave the city because they required continuing psychiatric services and thus could not register at any boarding house. ${ }^{197}$ The court distinguished the zoning law upheld in Belle-Terre and held that, because the plaintiffs were evicted as a result of their continuing psychiatric needs, the ordinance burdened their right to travel. ${ }^{198}$

To require that a statute facially discriminate against migrants would set the dangerous precedent of permitting a municipality to remove an entire class of people from its borders. Such a facial discrimination requirement would have saved the ordinance in Stoner, thus permitting Long Beach to evict inentally ill patients froin its jurisdiction. Similarly, an ordinance that prohibits sleeping in all outdoor public areas permits a municipality to drive all homeless people out of its jurisdiction. If a municipahity can avoid a right-to-travel violation and evict an entire class of persons by claiming that its ordinance does not facially discriminate agamst migrants, it could impose comprehensive regulations on conduct, thereby creating a largely homogeneous enclave into which migration would be nearly impossible. ${ }^{199}$

This nation's notion of liberty also compels the conclusion that the right to travel necessarily includes the right to remain in a jurisdiction. The Supreme Court has stated that the right to travel includes the right to "migrate, resettle, find a new job, and start a new life."200 This language underscores the Constitution's intolerance of a law that effectively evicts an entire class of people: Just as a government should not be allowed to imprison those dissatisfied with the status quo, it should not be allowed to expel those who have become a burden or a source of friction or unrest. ${ }^{201}$ Facial discrimination against migrants therefore

195. Id. at 178.

196. Id. at 179 .

197. See id.

198. "[B]ecause of this ordinance, the plaintiffs are not able to register or are subject to eviction from these hotels because of their mental health problems. A reading of this ordinance indicates clearly that it is exclusionary in nature, and, therefore, a restriction on a citizen's right to travel." Id. at 180 (emphasis added). Thus, though the ordinance did not facially discriminate against migrants, the court found a right-to-travel violation.

199. See L. TRIBE, supra note 127, at 1381 n.20.

200. Shapiro v. Thompson, 394 U.S. 618, 629 (1969); see also Memorial Hosp. v. Maricopa County, 415 U.S. 250, 255 (1974).

201. Cf. L. TRIBE, supra note 127, at 1382 (discussing the unconstitutionality of stripping the citizenship rights of soldiers given dishonorable discharges). 
cannot be a prerequisite to a finding of burden on migration. A showing of purpose and direct negative effects inust suffice.

\section{E. Right-To-Travel Summary}

The Arizona appellate court in Seeley $v$. State ${ }^{202}$ misapplied the right-to-travel analysis. In affirming the defendants' convictions for violating Phoenix's antisleeping ordinance, the court rejected their right-totravel claim ${ }^{203}$ because the law did not facially discriminate among residents, and because, in the court's view, prohibiting sedentary activities did not discourage inoveinent. ${ }^{204}$

The Arizona court mistakenly concluded that the riglit to travel was not burdened by the Phoenix law: It failed to recognize both the penalty incurred by the hoineless and the relevance of purpose and effect. The crucial issues are whether the ordinance penalizes migrants for exercising their riglit to travel and whether its purpose and effect is to erect a direct barrier to travel. A law with such a purpose and effect should be held unconstitutional, even in the absence of facial discrimination among residents. ${ }^{205}$ Because the defendants in Seeley, though not recent migrants to Phoenix, were arrested for engaging in an activity necessary to bive (that is, sleeping), they were penalized for migrating to the city (or for failing to leave the city). Because the purpose and effect of Phoenix's antisleeping ordinance are to penalize travel by the hoineless, to evict the houneless, and to erect a direct barrier against their in-migration, the ordinance burdens the right to travel. ${ }^{206}$

\section{III \\ EQUal Protection ANALYsis}

In Part II, this Cominent established that ordinances that proscribe outdoor sleeping in all public areas burden the fundanental right to travel. Using the former antisleeping ordinance of Santa Barbara, California $^{207}$ as an example, Part III argues that this burden renders

202. 134 Ariz. 263, 655 P.2d 803 (Ct. App. 1982).

203. Seeley, 134 Ariz. at 266, 655 P.2d at 806 (defendants also claimed the statute was vague and overbroad, violated guarantees of equal protection, and was an invalid exercise of the city's police power).

204. Id. at 268,655 P.2d at 808 . The court also found the record inadequate to show that the ordinance chilled visitor influx. Id.

205. See generally supra notes 164-201 and accompanying text.

206. Under this analysis, the law's prohibition of sedentary activities (an issue discussed by the Seeley court) is irrelevant.

207. Santa Barbara, Cal., Municipal Code $\S 15.16 .085$ provided:

Seetion 1. Over a period of several months, there has been an alarming increase of criminal behavior which violates various laws and is often violent in nature. $A$ major portion of this increase in criminal behavior is caused by a transitory population. In addition, this transitory population is frequently a viction of such criminal behavior. In 
antisleeping ordinances unconstitutional under an equal protection analysis. $^{208}$ Part III begins by briefly reviewing relevant Supreme Court equal protection jurisprudence.

Under the Supreme Court's equal protection doctrine, laws burdening fundamental rights are subjected to "strict scrutiny."209 For a statute to survive this strict-scrutiny analysis, the proponent of the law must

order to protect the community from such criminal behavior, it is necessary to . . . prohibit

sleeping... within the city.

....

Section 3. Unlawful areas to sleep

It shall be unlawful for any person to sleep in:

(1) Any public park ....

(2) Any public street;

(3) Any public park or public area, improved or unimproved;

(4) Any public beach ....

....

Section 5. This ordinance is hereby declared to be necessary as an emergency measurc

for the immediate preservation of public health, safety, and welfare . . . .

See People v. Davenport, 176 Cal. App. 3d Supp. 10, 13, 222 Cal. Rptr. 736, 737 (1985) (quoting statute), cert. denied, 475 U.S. 1141 (1986). In August 1986, the Santa Barbara city council significantly narrowed the scope of its antisleeping ordinance. See supra note 9 . The unrevised ordinance is used for demonstrative purposes only.

208. The equal protection clause of the fourteenth amendment provides that "No State shall ... deny to any person within its jurisdiction the equal protection of the laws." U.S. CoNST. amend. $\mathrm{XIV}, \S 1$.

209. Cleburne v. Cleburne Living Center, 473 U.S. 432, 440 (1985). "Strict scrutiny" is also given to laws that discriminate against a "suspect class." A classification receives suspect status if the group classified is deemed to be a "discrete and insular minority." See Graham v. Richardson, 403 U.S. 365, 372 (1971) (ruling that classifications based on alienage are subject to strict scrutiny because "aliens as a class are a prime example of a "discrete and insular minority" ").

It is unlikely that the homeless will be deemed a "suspect class." Suspect status has been given only to classifications based on race, national origin, and alienage, and quasi-suspect status applies only to gender and illegitimacy classifications. The traditional factors used to determine the suspectness of a classification are whether the classified group shares an "unalterable trait," whether it has a tradition of political powerlessness, and whether it suffers from a stigma of inferiority caused by a history of discrimination. See generally City of Cleburne v. Cleburne Living Center, 473 U.S. 432 (1985).

The homeless do share some of these characteristics. Though homelessness is not an unalterable trait, the homeless are generally denied the right to vote, a traditional measure of political power. They are stigmatized insofar as they are stereotyped and perceived as inferior, and they have suffered a history of discrimination. See generally Foote, supra note 67; Reid, Law, Politics, and the Homeless, 89 W. VA. L. REv. 115, 135-42 (1986); Note, Homelessness in a Modern Urban Setting, supra note 19, at 754-55 \& nn.16-17; Note, Building a House of Legal Rights: A Plea for the Homeless, supra note 19, at 538-40 \& nn.42-53.

The Supreme Court, however, has recently indicated its unwillingness to create more suspect classes. In Cleburne, the Court refused to extend suspect status to those suffering from mental retardation. It pointed to the group's "reduced ability to cope," 473 U.S. at 442 , to its present ability to attract the attention of lawmakers (as evidenced by much recent favorable legislation), and to the difficulty in distinguishing the retarded from other groups that also would demand suspect status. Id. at $442-46$.

Under this analysis, the homeless probably do not qualify for suspect status. Apart from not sharing an unalterable trait, they have attracted the attention of lawmakers (though not to a substantial degree), they are not a homogeneous group, and a large proportion are mentally ill and therefore presumably have a "reduced ability to cope." See Reid, supra, at 135-42. 
demonstrate that the classification is necessary to "serve a compelling state interest." 210 This most demanding review rarely results in a statute being found constitutional. ${ }^{211}$ Because the right to travel is a "fundamental right,"212 antisleeping ordinances which burden the right to travel are subject to strict-scrutiny analysis.

To survive strict scrutiny, the proponent of the antisleeping ordinance must demonstrate that the state interest advanced by the ordinance is "compellimg" and that the ordinance is necessary to serve the stated interest. The Santa Barbara, California antisleeping ordinance ${ }^{213}$ advanced five potential state interests: (1) responding to "an alarming increase in criminal behavior;" ${ }^{114}$ (2) protecting transients who may be the victims of the increase in crime; (3) keeping outdoor public areas clean and aesthetically appealing; (4) keeping public ways unobstructed; and (5) ridding the city of its homeless population.

Though respondimg to an increase in crime can possibly be deemed compelling, banning outdoor sleeping is not necessary to achieve this interest. Sleeping persons pose no criminal danger. The ordinance therefore rests on the assumption that those who sleep outside (the homeless population) are, during their waking hours, disproportionately responsible for the increase in crime. However, the Supreme Court rejected a similar notion in Edwards v. California: ${ }^{215}$ "[W]e do not think that it will now be seriously contended that because a person is without employment and without funds he constitutes a 'moral pestilence.' Poverty and mimorality are not synonymous." 216

The law is also overbroad. Even if the transient homeless community is especially prone to criminal activity, the city can use other less restrictive methods to combat the increase in crime. It can increase the

210. Shapiro v. Thompson, 394 U.S. 618, 638 (1969) (emphasis omitted). Unlike laws that burden fundamental rights, classifications created by social and economic legislation are given a very deferential standard of review under the equal protection clause. Classifications created by this type of legislation satisfy the equal protection clause as long as they are "rationally related to a legitimate state interest." New Orleans v. Dukes, 427 U.S. 297, 303 (1976). Two classifications, gender and illegitimacy, receive heightened scrutiny. To be valid, such classifications must be substantially related to an important state interest. See Craig v. Boren, 429 U.S. 190, 197 (1976); Mathews v. Lucas, 427 U.S. 495, 510 (1976).

211. Forty-five years have elapsed since the Court's only affirmance of a statute reviewed under the strict scrutiny standard. See Korematsu v. United States, 323 U.S. 214 (1944); see also Dunn v. Blumstein, 405 U.S. 330, 363-64 (1972) (Burger, C.J., dissenting); Gunther, The Supreme Court, 1971 Term-Foreward: In Search of Evolving Doctrine on a Changing Court: A Model for a Newer Equal Protection, 86 HARv. L. REv. 1, 8 (1972) (describing the strict scrutiny standard as “' 'strict' in theory and fatal in fact").

212. Shapiro v. Thompson, 394 U.S. at 638.

213. Santa Barbara, Cal., Municipal Code $\S 15.16 .085$, supra note 207.

214. Id.

215. 314 U.S. 160 (1941).

216. Id. at 177. 
police presence in areas frequented by the homeless, warn local residents and businessmen about the crime problem, and more strictly enforce those existing criminal statutes that do not impinge upon the right to travel.

The second potentially compelling state interest advanced by the antisleeping ordinance-protecting transients from crime ${ }^{217}$-is also overbroad. Again, the city has other less burdensome options available, such as increasing the police presence in areas where the homeless congregate. Indeed, enforcenent of this ordinance may prove counterproductive. Because the law's effect is to drive transients out of the community, it may force homeless individuals to imgrate either to more dangerous skid row neighborhoods (where people have traditionally been allowed to sleep outdoors), or to public shelters which many homeless advocates believe are more dangerous, crime-ridden, unsanitary, and drug-infested than the outdoor public areas where the homeless often sleep. $^{218}$ Because the ordinance is not necessary to protect the homeless, this state interest cannot justify the resulting burden on travel.

The other interests ostensibly served by the sleeping ban are not "compelling." 19 Though keeping parks and beaches clean and aesthetically appealing to local residents is a legitimate state interest, it is not compelling in the constitutional sense. 220 Similarly, any interest in

217. See supra note 207; see also People v. Davenport, 176 Cal. App. 3d Supp. 10, 222 Cal. Rptr. 736 (1985), cert. denied, 475 U.S. 1141 (1986); Seeley v. State, 134 Ariz. 263, 267, 655 P.2d 803, 807 (Ct. App. 1982); cf. United States v. Hogue, 752 F.2d 1503, 1505 (9th Cir. 1985) (banning sleeping in an automobile in a national park protects car occupants).

218. See supra notes 49-53 and accompanying text (discussing conditions of public shelters).

219. The Supreme Court has apparently never exphicitly defined the term "compelling state interest." However, the results of the Supreme Court's strict scrutiny cases suggest that only a very few, if any, state interests will be deenied compelling. See Dunn v. Blumstein, 405 U.S. 330, 363-64 (1972) (Burger, C.J., dissenting).

220. The Supreme Court has recently referred to such an interest as "substantial." In Clark v. Community for Creative Non-Violence, 468 U.S. 288 (1984), a first amendnient case, the Court upheld a ban on overnight sleeping in national parks. The Court characterized the regulation as promoting the substantial government interest in limiting "wear and tear" on its parks. Id. at 299. See also People v. Trantham, 161 Cal. App. 3d Supp. 1, 15, 208 Cal. Rptr. 535, 543 (1984) (government has legitimate interest in limiting "wear and tear" on park properties) (quoting Clark, 468 U.S. at 299).

Several eourts, including the Suprenie Court, have stated that a "substantial" state interest is alone insufficient to satisfy the "compelling" state interest requirement. See, e.g., Williams v. Rhodes, 393 U.S. 23 (1968) (ruling that, despite the presence of several "substantial" state interests, the "compelling state interest" standard was not satisfied); White v. Keller, 438 F. Supp. 110, 117 (D. Md. 1977) (stating that the right of prison visitation "is not a fundamental right requiring a compelling state interest [but rather is] a non-fundamental right which can be restricted by the state on a lesser showing of a substantial state interest") (emphasis in original).

The Court in Clark also noted that the law "neither attempts to ban sleeping generally nor to ban it everywhere in the parks." Clark v. Community for Creative Nonviolence, 468 U.S. at 295 (emphasis added). This Comment involves only those ordinances that prohibit outdoor sleeping in all the public areas of a particular jurisdiction. Because the issue in Clark involved merely a limited 
keeping public rights of way unobstructed ${ }^{221}$ is not compelling and, in any event, can be served by a more narrowly tailored ordmance. Santa Barbara can prohibit obstructions witlout banning sleeping in public areas sucl as parks and other locations where tlie flow of pedestrian and vehicular traffic is not impeded by the homeless.

Fimally, the city's inain imphicit interest, ridding the community of its homeless population, is impermissible. The Supreme Court las declared on many occasions that prohibiting the migration of needy persons into a jurisdiction is not a permissible state interest, ${ }^{222}$ regardless of any effect on the financial health of the jurisdiction. ${ }^{223}$ As the Court stated in Edwards y. California, ${ }^{224}$ the Constitution prohibits "attempts on the part of any single State to isolate itself from difficulties common to all."225

Because antisleeping ordinances such as the one formerly adopted by Santa Barbara are not necessary to serve any compelling state imterest, they do not survive strict scrutiny. They are therefore unconstitutional as a violation of the fundanental right to travel.

\section{CONCLUSION}

The homeless are migrating away from skid row areas and into more affluent residential and busmess districts, often to the displeasure of local mercliants, residents, and government officials. In response, many municipalities are adopting antisleeping statutes whicl burden the fundamental right to travel. Given that many cities eitler refuse or carmot afford to provide adequate and safe shelter sufficient to meet the growing demand, the use of these laws will become a more common method of addressing the growing problem of homelessness. The courts that have reviewed these laws have reaclied conflicting decisions and have not adequately addressed the constitutional right-to-travel issues posed by such ordimances.

antisleeping regulation challenged only on first amendment grounds, the holding of Clark is inapplicable to this discussion.

221. See Seeley v. State, 134 Ariz. 263, 267, 655 P.2d 803, 807 (Ct. App. 1982).

222. See, e.g., Shapiro v. Thompson, 394 U.S. 618, 629 (1969) ("[T]he purpose of inhibiting migration by needy persons into the State is constitutionally impermissible."); Edwards v. California, 314 U.S. 160, 172-73 (1941); see also Morris, Legislative Motivation and Fundamental Rights in Constitutional Law, 15 SAN Diego L. REv. 953, 986 (1978) ("[T]he equal protection clause and the ... the right to travel . . . are centrally concerned with the prevention of repeated attempts . . . to exclude undesirable persons, such as paupers . . . for economic or other selfish reasons.").

223. See, e.g., Memorial Hosp. v. Maricopa County, 415 U.S. 250, 263 (1974) ("The conservation of the taxpayers' purse is simply not a sufficient state interest to sustain a durational residence requirement which, in effect, severely penalizes exercise of the right to freely migrate and settle in another State.").

224. 314 U.S. 160.

225. Id. at 173 . 
Antisleeping laws burden the fundamental right to travel. Their purpose and effect are to erect a barrier which bans the migration of homeless people into the jurisdiction and to drive out those homeless individuals who already hive in the community. These ordinances also burden the right to travel because they penalize the migration of the homeless into the jurisdiction by denying them a basic necessity of hife.

Because ordinances that prohibit outdoor sleeping in all public areas are not necessary to serve a coinpelling state interest, they violate the fundamental right to travel. Courts inust therefore rule that they are unconstitutional.

By turning to the criminal justice systein to deal with the problein of homelessness, cities and towns ignore the sources of the problen, thus allowing it to worsen. Ultimately, the solution to this problein must coine from the Congress and the state legislatures in the form of greater support services for the deinstitutionahized mentally ill and a commitinent to resolve the low-income housing crisis. The solution certainly will not come from funnelling the hoineless through the criminal justice systein without regard for their constitutional rights. 